\title{
Graduate unemployment in South Africa: Perspectives from the banking sector
}

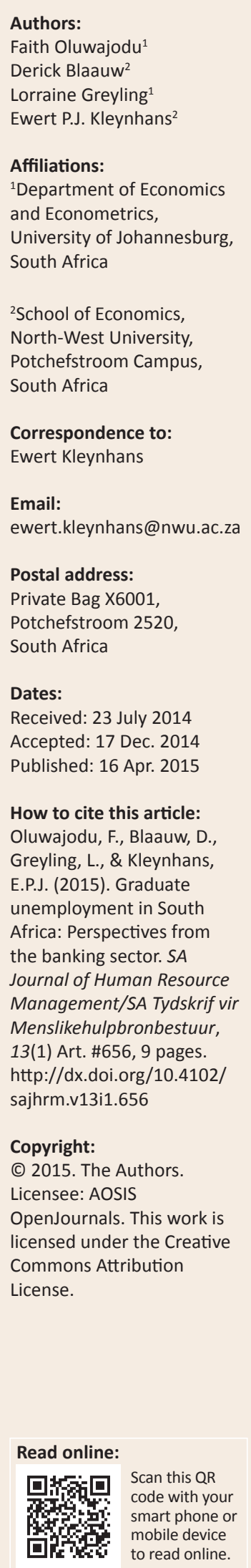

Orientation: South Africa is experiencing growth in its graduate labour force, but graduate unemployment is rising with the overall unemployment rate. Graduate unemployment is problematic, because it wastes scarce human capital, which is detrimental to the economy in the long run.

Research purpose: This study explores the perceived causes of graduate unemployment from the perspective of the South African banking sector.

Motivation for the study: Researchers have conducted various studies on graduate unemployment in South Africa and across the globe, but few studies have been conducted on the causes of graduate unemployment. There appear to be some gaps in the literature; therefore, other problems and solutions to graduate unemployment have to be explored.

Research approach, design and method: The researchers followed a survey design. Questionnaires and face-to-face interviews were used as research instruments to identify the perceived causes of graduate unemployment in the banking sector of South Africa. Research participants were unemployed graduates, recently employed graduates and graduate recruitment managers in the banking sector.

Main findings: The study shows that several factors are perceived to be the causes of graduate unemployment in the South African banking sector. These include: skills, institution attended by graduate and differences in expectations from employers and graduates.

Practical/managerial application: The findings have implications for educational institutions and companies that are encouraged to consider possible solutions to resolving the causes of graduate unemployment.

Contribution/value-add: This study is one of the first papers to investigate the causes of graduate unemployment in the South African banking sector. It provides a rich platform for further studies and replication in other sectors, especially within the African context.

\section{Introduction}

Unemployment is a socio-economic challenge, with economic costs and many other challenges. It reduces economic welfare, reduces output and erodes human capital. These costs make unemployment a high priority in countries such as South Africa.

The South African economy has been experiencing rising unemployment over many years. In 2011, the unemployment rate was at $24.2 \%$ and in 2013 it had increased to $25.2 \%$ (Statistics South Africa, 2014). At the same time, there was a structural change observed in labour demand trends shifting towards high-skilled workers (Bhorat \& Jacobs, 2010). This structural change has led to the conclusion that the unemployment problem in South Africa is structural, in the sense that the poorly educated workers, who constitute the vast majority of the labour supply, cannot find employment due to insufficient demand for low-skilled resources (Pauw, Bhorat \& Goga, 2006).

The youth faces even higher rates of unemployment when compared to older members of the labour force all around the world. Since the global financial crisis this is even more pronounced (Levinsohn, Rankin, Roberts \& Schöer, 2014). In the case of South Africa, this phenomenon is particularly acute.

Young South Africans, who are defined as those within the age group of 15-34 years (Department of Basic Education [DBE], 2011), have, however, become better educated over the last decade. This trend can be observed in the increasing enrolment rate at tertiary educational institutions. According to Broekhuizen and Van der Berg (2013), 57.9\% of the labour force has completed 
their education at a tertiary level. This implies that the size of the graduate labour force is increasing in accordance with the structural change in demand for high-skilled workers (Daniel, 2007).

However, unemployment amongst young South Africans is still very high and is increasing. It furthermore displays significant differences across racial lines (Levinsohn et al., 2014). Levinsohn et al. (2014) further indicate that in the second quarter of 2012, the broad unemployment rate for those between 20 and 24 years of age was higher than $60 \%$. In the case of Africans in this category the figure is even higher (almost two-thirds). This rate increased by more than ten percentage points between 2008 and 2012. This is in stark contrast with the less than $20 \%$ in the white racial category for the same age group. Given the increasing level of both youth unemployment and graduate unemployment in particular, the current study investigates unemployment amongst graduates in the South African banking sector.

\section{The rationale for studying unemployed graduates}

Despite the growth in the graduate labour force, graduate unemployment in South Africa appears to be rising together with the overall unemployment rate. Although graduate unemployment only accounts for $5.9 \%$ of the changes in overall unemployment from 1996 to 2012, the actual unemployment rate for this education group has increased from 5.4\% during 1995 to 7\% in 2012 (Broekhuizen \& Van der Berg, 2013).

Although the absolute size is small, this increase shows that graduate unemployment has increased over time. It is important to improve the understanding of the reason for this phenomenon. In addition to the statistics highlighted, graduate unemployment is also an important area of study because theory suggests that the South African economy experiences severe skills shortages, whilst the economy is unable to generate sufficient job opportunities for graduates. This seems to contradict studies suggesting that the higher a participant's education level, the higher the probability of finding employment (Oosthuizen, 2005). It is therefore important to identify the necessary requirements for graduates to become employed.

In this study, a graduate is defined with reference to degree holders, including postgraduate degrees. Unemployed graduates will be denoted as recently graduated youths (16-35 years) without employment.

Studying graduate unemployment is important as the ages 20-24 are the ages when the trajectory of labour market involvement and outcome are shaped (Levinsohn et al., 2014). Obtaining initial work experience is a key objective of young graduates in this age category. Failing to do so may lead to undesirable outcomes which may be irreversible in many cases. Banerjee, Galiani, Levinsohn, McLaren and Woolard (2008) suggest that previous work experience is correlated with whether one has a job currently or not. Therefore, finding a first job is fundamental for people's lifetime work trajectory (Levinsohn et al., 2014).

Graduate unemployment is also an important area of study because unemployment amongst graduates is potentially damaging to the economy. The South African government is aware of this problem and has used different policies in an attempt to address this problem. One of the strategies that were designed to solve the problem of graduate unemployment is known as the Joint Initiative for Priority Skills Acquisition (JIPSA). Its strategy proposes the implementation of special training programmes, bringing back retirees or expatriates to work in South Africa and attracting new immigrants (Pauw et al., 2006).

This strategy has been able to provide some solution to the problem of graduate unemployment. It has, however, not been able to decrease graduate unemployment, because there are more graduates searching for jobs (Pauw et al., 2006).

Various researchers have conducted studies on this kind of unemployment. Naong (2011), for example, analysed the reason why graduates struggle to find employment and found that most graduates struggle to find employment because they have chosen the wrong field of study and because of other weaknesses in the South African educational system. He proposed the promotion of an entrepreneurial culture in schools to solve the problem.

Sha (2006) studied graduate unemployment amongst graduates with degrees in computer science in Malaysia. Conclusions on reasons for graduate unemployment were based on the perspectives of both graduates and employers. The results revealed that graduates are of the opinion that employers are to be blamed for their being unemployed, whilst employers perceive the attitude of computer science graduates towards work as negative. This makes employers reluctant to hire new graduates.

Although these and other studies have been able to analyse the graduate unemployment situation in South Africa and elsewhere, there appear to be some gaps in the literature. Most of the solutions to graduate unemployment are centred on education, whilst education is not the only cause of graduate unemployment in South Africa (Lie, 2007). As a result, other problems and solutions to graduate unemployment need to be explored. Not many studies have been conducted recently on graduate unemployment in South Africa, keeping researchers and policymakers uninformed. This study on graduate unemployment will also explore other possible causes of graduate unemployment and its solution.

In order to contribute to the body of literature on graduate unemployment, the objective of the study is to investigate the labour market for graduates in South Africa with a focus on the banking sector. The focus is on the banking sector because it is one of the largest employers of labour with various higher qualifications and skills in South Africa. Standard Bank, for example, has 52000 employees. The banking sector 
is also considered amongst the top contributors to long-run economic growth (BANKSETA, 2011).

The study will explore the supply side of the labour market, which consists of unemployed graduates and recently employed graduates, as well as the demand side, represented by employers in the banking sector. This research intends to study the basic aspects that are often overlooked or overstated when addressing graduate unemployment.

\section{Literature review on graduate unemployment}

Various explanations are provided for the causes of graduate unemployment. Some ascribe it to the lack of employment that is caused by a lack of employability, type of qualification obtained as well as field of study, quality of secondary school education, quality of tertiary education, high expectations, job search and work experience.

Various authors have offered definitions for employability. Weligamage (2009) and Sha (2006) agree, however, that employability relates to the skills and attributes needed to gain employment and progress in an industry.

A survey conducted on graduates by Griesel and Parker (2009) highlighted four main categories of skills and attributes that employees look out for when recruiting graduates. Basic skills, intellectual ability, workplace skills, applied knowledge and interactive skills were regarded as most important.

South African graduates are often unsuccessful in the recruitment phase, because they lack some of the required skills. Pauw et al. (2006) argue that many of these students who lack the required skills come from historically black institutions where they did not develop these skills or acquire work experience. As a result, graduates become disadvantaged because the skills they learned are not required in the working environment.

Lie (2007) argues that graduates should not be entirely blamed for the unemployment condition. Graduates, employers, government and universities are all involved. Graduates are more academically oriented and lack awareness of the latest developments and applicable skills. Graduates generally believe that their education and skills are sufficient and universities consider their graduates to be well prepared for the workplace. At the same time, employers perceive graduates to lack the vital skills for employment. Such perspectives must be addressed to enhance the employability of graduates.

The quality of secondary education was also highlighted as another reason for graduate unemployment. According to Mlatsheni (2005), fewer students who matriculated passed with exemption and students are regarded as functionally illiterate. This means that an average Grade 12 student who has just matriculated does not possess adequate writing, mathematical and communication skills to perform at university level because the quality of secondary school education is low. As students are not prepared to enter and succeed in further higher learning, high dropout rates are experienced (Pauw et al., 2006).

Differences in the quality of tertiary institution also lead to graduate unemployment. These institutions can be grouped into historically white institutions (HWIs) and historically black institutions (HBIs). Graduates from HWIs have much better employment prospects than those from HBIs. HWIs graduates are absorbed into the labour market faster after obtaining degrees (Bhorat \& Visser, 2010).

Another reason why HWIs graduates are more employable than those from HBIs relates to the fact that HBIs enrol students in fields of study with low employment prospects. Employers are biased towards employing students who have graduated from certain universities because of their perception of the universities' educational standards and culture. Generally, employers have the perception that 'HBIs are much poorer in ensuring success in the labour market for their client base than HWIs' (Bhorat \& Visser, 2010, p. 5).

Graduate unemployment may also be due to graduates' unrealistically high expectations. They usually assume that their qualifications must ensure high salaries and managerial positions immediately (L.M. Luan, personal interview, 24 October 2012). Sirat and Shuib (2012) found that many graduates expect to be paid high salaries, but have a bad attitude towards work. They do not understand the importance of the process of gaining work experience over time. With such expectations, no graduate would wish to start at a low level. Consequently, they select jobs and prefer to remain unemployed until they get their dream employment (Pauw et al., 2006). From the employer's perspective, they view graduates as new entrants with a degree, but lacking the required soft skills and experience to work effectively in the workplace (L.M. Luan, personal interview, 24 October 2012). Employers, therefore, pay less and train the graduates according to the needs and demands of the workplace. High expectations amongst graduates will therefore increase graduate unemployment if the graduates' perceptions persist.

Another reason for high graduate unemployment relates to job search activities. Moleke (2010, p. 93) defines job search as a 'normal occurrence which work seekers use as a form of investment to enhance their position in the labour market'. Job search is therefore seen as an activity that requires time and effort to achieve a goal, which in this case is a job. For graduates, the process of searching for a job takes longer, because graduates are seen as new entrants without working experience. They therefore need to go through job advertisements, complete application forms, write psychometric tests in some cases, attend interviews and write a formal assessment before a permanent offer is made (L.M. Luan, personal interview, 24 October 2012). Moleke confirms this. He found that over half of the unemployed graduates had been searching for employment for more 
than a year and that African graduates search longer, some having searched for more than 2 years (L.M. Luan, personal interview, 24 October 2012). Exploring the possible reasons for this observation is an important research agenda going forward.

\section{Method}

This section describes the research method followed in this study.

\section{Research participants}

The population from which the sample was drawn was divided into two groups, namely: the graduate group (the unemployed graduates and recently employed graduates) and the human resource (HR) group (graduate recruitment managers). Graduate recruitment managers were selected for the HR group because they play a significant role in recruiting, managing and training graduates. They were selected from the four biggest banks in South Africa, namely ABSA, Nedbank, First National Bank and Standard Bank of South Africa. These four banks were chosen because they are the largest employers of graduates in the banking sector. Each bank annually employs between 100 and 200 graduates (L. Ntuli, personal communication, 28 October 2012). Graduates with diverse qualifications are employed, ranging from engineering, mathematics, history, economics and finance. These four banks were therefore ideal areas of investigation for possible causes of graduate unemployment in the South African banking sector. For the second group, the graduate recruitment managers, the study made use of the purposeful sampling method. The purposeful sampling method was selected based on the fact that, due to their key position in the recruitment cycle, the graduate recruitment managers will assist in providing information that is important to the study (Greener, 2008).

The unemployed graduates were selected from the South African Graduate Development Association (SAGDA) database. SAGDA's database was used because it contains information such as the names of graduates, age, gender, qualification, major subjects, location of an individual and institution. Their database also has 2405 records of unemployed graduates (Z. Ngewu, personal communication, 28 October 2012). All this information assisted in the compilation of an unbiased sample of unemployed graduates and postgraduates with diverse qualifications. A sample size of 400 unemployed graduates and 400 recently employed graduates (total sample of 800) was envisaged for the research. This study used a stratified random sampling method for the first group, the graduates, to determine the sample units, because the total population is divided into groups that differ along selected characteristics such as academic qualifications and types of institutions. The sampling was done by separating each graduate group into qualifications offered by universities and selecting a simple random sample from each group. According to previous conversations with graduate recruitment managers (R. Tshidi, personal interview, 10 September 2012), 50\% of graduates employed by the banks have Bachelor of Commerce (BCom) qualifications, $40 \%$ of graduates have Bachelor of Science (BSc) degrees, whilst $10 \%$ of the graduates employed by the banks have Bachelor of Arts (BA) qualifications.

Based on the percentages of recruitment by qualification, $50 \%$ of the sample in the graduate group (unemployed and recently employed graduates) were BCom graduates, $40 \%$ of the graduate group were BSc graduates and $10 \%$ of the graduate group were BA graduates. The authors of this study acknowledge that different qualifications have various subjects and in order to account for the subjects, this study randomly selected students with different subjects in each qualification group. For example, students with a major in economics, marketing or finance will be randomly selected from the BCom group. Because their qualifications theoretically enable them to be employed in various sectors, the respondents' endeavour to be employed in the banking sector as well was specifically tested by including a question in the survey instrument to verify that the person did apply at one or more of the banks included in this study.

Recently employed graduates were selected from the particular banks. They were selected because they have passed through the process of applying for a job as a graduate and were able to assist in identifying possible requirements to gain employment as a graduate and to prepare for the workplace.

\section{Research approach}

For this investigation, the researchers applied a surveybased approach. The survey was based on questionnaires distributed to employed candidates who had recently graduated and unemployed graduates, as well as face-to-face interviews conducted with graduate recruitment managers of the banks. The intention was to gain an understanding of the perceived causes of graduate unemployment in the banking sector.

\section{Research instruments}

This research utilised survey questionnaires that varied according to the groups. Closed and open-ended online and manual questionnaires were designed for the graduate group, unemployed and recently employed graduates, whilst openended and face-to-face interview questionnaires were used for the HR manager group. The questions were drawn from the literature on the causes of graduate unemployment and an understanding of the banking sector.

The survey questionnaire used in the case of unemployed graduates consisted of five separate sections. The first was designed to collect demographic data for cross-sectional analysis. Next followed questions relating to the choice of university and degrees, followed by two sections on the 
application and job search process and the final section considered the causes of graduate unemployment.

The survey questionnaire used in the case of recently employed graduates was designed in the same way, except for the sections focusing on the transition to the workplace and their expectation versus reality. The questionnaire also consisted of five separate sections, starting with demographic and eductional sections designed in the same way as described above. In addition, candidates were asked about the number of job offers received and the time period from application to offer. Section D asked candidates about their experience from study to employment, whether the skills that they had acquired during their period of study were adequate and whether their employers had the same views about their skills. The last section compared the expectations of graduates before they were employed to their experience in the workplace.

The graduate manager survey questionnaire was unstructured. The questions formulated in this questionnaire considered the company's intention to hire graduates and the importance of recruitment strategies, such as the graduate recruitment programme annually designed for graduates. The next questions focused on the selection process when hiring graduates as well as the post-selection process. This covers what happens after graduates are hired, the cost involved after graduates are hired, the skills level of the graduate before and after the graduate has been hired, the retention rates of graduates and the incentives offered to retain graduates.

\section{Data collection procedure}

For the unemployed and recently employed graduates, an online survey questionnaire was created with the help of an online research website known as Question Pro. The link to the survey was customised and posted on the SAGDA website (SAGDA, 2012). An online survey was chosen because it is easily accessible. For those who did not have access to the Internet, the survey was manually printed and distributed to a list of graduates, which was made available by SAGDA.

The HR managers were also approached to administer the survey during the training of graduates, when they felt it would be most convenient. For the graduate recruitment managers, questions were sent via email and contact details were collected during a South African Graduate Recruitment Association's (SAGRA) conference. Meetings were booked in order to conduct face-to-face interviews.

\section{Data sorting process}

From the original 800 completed surveys, 170 were scrapped due to incompleteness and cases where the unemployed subsequently obtained employment. The survey on the graduate recruitment managers was easier to conduct, as the survey was interview based. In total, the remaining sample comprised 300 unemployed graduates, 330 recently employed graduates and four graduate recruitment managers.

\section{Data analysis}

The responses to each of the survey questions for the unemployed graduates and recently employed graduates were compiled in a comparative table to understand the common views, the disagreements of the graduates and the perceived changes in graduate unemployment.

Content analysis, which is a form of analysis that focuses on actual content and information (Stemler, 2001), was used to analyse the results derived from the graduate recruitment managers. Results were in the form of written responses and notes from the interviews. Each question in the interview was analysed in comparison to the responses from the four banks. After a within-group comparison the results of both groups (i.e. graduates and recruitment managers) were compared. Areas of disagreements and common interests between the groups were analysed to understand the dynamics of the graduate labour market. The results were then used to offer tentative policy recommendations about a possible solution to the causes of graduate unemployment.

\section{Results}

\section{Graduate group: Unemployed and recently employed graduates (supply side)}

\section{Demographic characteristics}

Even though the survey was sent to both men and women, there was a slightly higher response rate from men. Approximately half of the unemployed graduate respondents were in the age bracket 21 to 24 . Based on age, the assumption could be made that many people graduate in the age bracket 21 to 24 , but are unemployed. Of the recently employed graduates, 36\% fell between the ages of 25 and 30 . Based on these findings, another assumption is that more graduates between the ages of 25 and 30 gain employment in the banking sector. These assumptions are in line with Altbeker and Storme's (2013) findings that younger graduates are more likely to be unemployed than older graduates, because employers are more reluctant to hire younger graduates.

The view that there seems to be a change in graduate unemployment in the banking sector in terms of race is confirmed in Table 1. The banking sector now hires more black graduates, indicating a directional hiring change from hiring white graduates to hiring other races (Altbeker \& Storme, 2013). Taking the opposing view, Moleke (2010) argues that racial discrimination might be a cause of graduate unemployment as there are still more white graduates in the banking sector than there are black graduates. The findings of the current study did not support this. The modern economy, especially the banking sector, now hires any race as long as the graduate possesses the required skills and knowledge. The following statistics provide examples of this trend. In 2013, Africans' share in junior management positions in one of the big four banks in 
TABLE 1: Race distribution of sample (\%).

\begin{tabular}{lll}
\hline Race group & Unemployed graduates & Recently employed graduates \\
\hline Black & 40 & 45 \\
White & 16 & 10 \\
Mixed race & 32 & 27 \\
Indian or Asian & 12 & 18 \\
\hline Total & $\mathbf{1 0 0}$ & $\mathbf{1 0 0}$
\end{tabular}

Source: Own compilation from survey data, SAGDA database (South African Graduate Development Association [SAGDA]. [2012]. SAGDA database. Retrieved September 12, 2012, from http://www.sagda.org.co.za)

TABLE 2: Educational level of respondents (\%).

\begin{tabular}{lll}
\hline $\begin{array}{l}\text { Highest educational } \\
\text { qualification }\end{array}$ & Unemployed graduates & $\begin{array}{l}\text { Recently employed } \\
\text { graduates }\end{array}$ \\
\hline Undergraduate degree & 65.75 & 62 \\
Honours degree & 22 & 32 \\
Postgraduate diploma & 9.25 & 4 \\
Master's degree & 3 & 2 \\
\hline Total & $\mathbf{1 0 0}$ & $\mathbf{1 0 0}$ \\
\hline
\end{tabular}

Source: Own compilation from survey data, SAGDA database (South African Graduate Development Association [SAGDA]. [2012]. SAGDA database. Retrieved September 12, 2012, from http://www.sagda.org.co.za)

South Africa rose to 72\% from 68\% in 2011 (Barclays Africa Group Limited, 2013); 80\% of all new appointments are also from this group. As a result of higher demand for Africans in the banking industry turnover of African staff is slightly higher than the company's average as well (Barclays Africa Group Limited, 2013).

\section{Choice of university and degree}

The highest concentration of respondents in the unemployed graduate group came from the University of Fort Hare, followed by the University of Zululand, University of the Free State (UFS) and University of Limpopo. Graduate recruitment managers regard these universities as access universities that do not carry out regular career exhibitions or any form of graduate recruitment (L.M. Luan, personal interview, 24 October 2012). On the other hand, most of the recently employed graduates studied at the University of Johannesburg (UJ), University of Cape Town (UCT), University of the Witwatersrand (Wits) and University of South Africa. According to employers, these universities are visited regularly in terms of career awareness programmes, counselling and recruitment, because of their reputation of high educational standards, facilities and equipment. It then becomes easier for graduates from the non-access universities to gain employment and develop their careers.

The majority of the graduate group respondents were undergraduates and honours degree graduates, whilst very few possess master's degrees, as indicated in Table 2. Educational qualification alone is not the most important criterion for gaining employment, since the majority of the recently employed graduates are undergraduate degree holders. The sample of recently employed graduates showed that $32 \%$ have honours degrees, offering candidates a better chance to gain employment. It seems that a degree is not enough to gain employment. There are possibly other factors that qualify a graduate in the banking sector for employment.
TABLE 3: Perceived skills acquired (\%).

\begin{tabular}{lll}
\hline $\begin{array}{l}\text { What do you feel you have to offer potential } \\
\text { employers in terms of skills gained during } \\
\text { your period of study? }\end{array}$ & $\begin{array}{l}\text { Unemployed } \\
\text { graduates }\end{array}$ & $\begin{array}{l}\text { Recently employed } \\
\text { graduates }\end{array}$ \\
\hline Communication skills & 17.9 & 9.35 \\
Computer literacy skills & 13.23 & 13.23 \\
Presentation skills & 7.39 & 7.39 \\
\hline $\begin{array}{l}\text { Technical skills } \\
\text { Numeracy or quantitative literacy }\end{array}$ & 9.34 & 17.9 \\
\hline $\begin{array}{l}\text { Understanding of economics and business } \\
\text { realities }\end{array}$ & 6.23 & 6.23 \\
Research skills & 12.39 & 7.39 \\
Leadership skills, problem-solving skills & 6.23 & 6.23 \\
Ability to plan and execute tasks & 6.61 & 12.45 \\
independently & 6.61 \\
Flexibility & 8.56 & 8.56 \\
Creativity and innovation & 4.67 & 4.67 \\
\hline Total & 100 & 100 \\
\hline
\end{tabular}

Source: Own compilation from survey data, SAGDA database (South African Graduate Development Association [SAGDA]. [2012]. SAGDA database. Retrieved September 12, 2012, from http://www.sagda.org.co.za)

Results show that most of the recently employed graduates have part-time, internship and voluntary work experience, which gave them an advantage. This may provide another explanation for the observation from the data, which shows more employability from age 25 onwards when additional work experience is more likely. This is therefore not merely a case of workplaces who do not want to appoint younger candidates.

\section{Skills amongst graduates}

The kinds of skills perceived to be acquired by both groups during their period of study are illustrated in Table 3 . The majority of recently employed graduates felt that they had acquired communication, research and computer literacy skills during their period of study. The majority of the unemployed graduates felt that they had acquired the same set of skills as the recently employed graduates, and yet they are still unemployed. It is important to note that most of the skills ticked by the graduates during the survey were based on their feelings of the kind of skills they possess and not based on employers' perceptions. Therefore, graduates can be confident about their perceived set of skills, but this may be in contrast to the reality of the employers' experience.

\section{Expectations versus reality}

Most of the unemployed graduates and recently employed graduates expected to earn a salary within the salary bracket of R275 000-R300 000, as indicated in Table 4. This salary range does not differ from what the banks are currently paying graduates. The interviews with the graduate recruitment managers confirms that graduates are paid between R250 000 and R320 000 annually. Unemployed graduates' salary expectations are therefore not different from what employers offer, and Sirat and Shuib's (2012) argument about salary expectations could be questioned. Higher salary expectations, as suggested by Sirat and Shuib, do not necessarily hinder graduates from gaining employment in the case of the banking sector, as they desire what the industry offers. 
TABLE 4: Annual salary expectations.

\begin{tabular}{lll}
\hline $\begin{array}{l}\text { Annual salary } \\
\text { expectations (Rand) }\end{array}$ & $\begin{array}{l}\text { Unemployed } \\
\text { graduates (\%) }\end{array}$ & $\begin{array}{l}\text { Recently employed } \\
\text { graduates (\%) }\end{array}$ \\
\hline 150 000-175 000 & 6 & 4 \\
$175001-200000$ & 7 & 9 \\
$200001-225000$ & 6 & 15 \\
$225001-250000$ & 21.18 & 8 \\
$250001-275000$ & 16.65 & 14 \\
$275001-300000$ & 29.17 & 21 \\
\hline More than 300000 & 14 & 29 \\
\hline Total & 100 & 100 \\
\hline
\end{tabular}

Source: Own compilation from survey data, SAGDA database (South African Graduate Development Association [SAGDA]. [2012]. SAGDA database. Retrieved September 12, 2012, from http://www.sagda.org.co.za)

\section{Human resource group (demand side)}

The survey revealed that all banks have the same intention to hire graduates, which relates to a successful supply of suitable candidates and the development of special skills to suit the needs of the company. The fact that graduates are recruited every year emphasises that banks are willing to employ graduates. Banks' intentions to hire graduates are also illustrated by their development graduate programmes that enable the recruitment of new graduates every year.

The survey results indicated that banks mainly visit UCT, UJ, the University of Pretoria, Wits and the University of KwaZulu-Natal during their graduate selection and recruitment process. These universities are regarded as the top universities in South Africa, with sound reputations and high quality of education. Most important is that the banks had employed a number of graduates from these universities in the past and they were excellent performers.

Another important factor that determines which universities should be visited or which graduates should be recruited is cost. It was found that banks spend a large amount of money on career exhibitions and career awareness programmes to entice graduates every year. The cost of hiring a graduate involves career exhibitions at universities, which cost R180 000 plus the training cost of hiring a graduate, which is between R300 000 and R650 000 per graduate when training is outsourced to a third party. In addition to the training cost, a graduate's salary ranges between R250 000 and R320 000 and the salary scales annually increase by $6.9 \%$. These costs restrict the number of graduates employed every year and the number of universities visited.

The research concluded that banks prefer to employ slightly older graduates rather than younger graduates. Younger graduates are assumed to be too inexperienced and immature for the challenges of the working world (Biavaschi et al., 2013) and special recruitment and training programmes are expensive. This may again be linked to the notion that the somewhat older graduate may have acquired additional skills beyond ones linked to the degree itself.

It was also found that a graduate's qualification is regarded as an entry point of consideration, but it is not a guarantee for employment as a graduate needs more than academic training to function effectively. During the recruitment process, employers search for required skills and if it is sensed that a graduate lacks these required skills, the graduate will be declined. It can be deduced that graduates who rely exclusively on their qualifications tend to remain unemployed.

\section{Discussion}

The purpose of this study was to investigate possible causes of graduate unemployment in the banking sector through surveys of graduates and human resource managers.

It was found that slightly older graduates are more likely to be employed in the banking sector than younger graduates. Employers regard older graduates as more mature and experienced. It is therefore concluded that age might be a cause of graduate unemployment in the banking sector. The researchers do, however, consider the sample size as being insufficient to generalise in the affirmative.

In terms of race, South Africa is producing more black graduates every year and their unemployment rates are declining, compared to past years where more white graduates than black graduates were hired. This confirms L.M. Luan's (personal interview, 24 October 2012) findings. In other words, there has been a directional change in hiring white graduates to hiring other races. There has also been a move towards equality, as the focus has shifted to the required skills and knowledge that graduates possess.

The results suggest that the kind of institution that a graduate attends and the perception of employers about those institutions leads to higher levels of graduate unemployment amongst graduates from access universities. With the exception of the UFS, these are all HBIs. Graduates from the so-called non-access universities are preferred to those from HBIs because of employers' perceptions about these universities and the fact that they do not engage with employers to understand the right skills needed to be successful. When cost is taken into consideration, employers would rather spend their resources on candidates from non-access universities, as the cost involved in recruiting is expensive and it will only make sense to invest these large costs in candidates with the adequate skills.

The information provided by $\mathrm{HR}$ managers raises the question of endogeneity in terms of industry perceptions of top-class universities and the choice of where career exhibitions are held. The question is whether the existing perception of where top universities are located determines where career exhibitions are held. The exhibitions foster good relationships with those institutions, but at the same time this practice marginalises other institutions and thereby perpetuates the existing perceptions of them not producing good candidates. The cost factor and the fact that the universities with whom good relationships exist fulfil the demand for graduates may put candidates from other universities at a disadvantage. One way of overcoming this is 
for good graduates from other institutions to pursue postgraduate studies in the bigger centres where the perceived good quality institutions are situated. This may in itself reinforce the notion of these institutions providing top candidates. This aspect also requires further research and decomposition of the origin of postgraduate students at these preferred institutions.

The results have shown that educational qualification alone is not the only criterion for gaining employment in the banking sector. Advanced qualifications do, however, make candidates more likely to be employed. The survey shows that employers demand work experience, skills and certain qualifications based on their particular needs. This in itself can be a problem as the industry then does not contribute towards the building of experience.

In terms of labour demand, as the economy changes organisations change their business requirements, and changes in business requirements lead to changes in the qualifications and skills needed to suit the needs of the organisation. A graduate without a qualification or skill that is needed by the organisation will therefore remain unemployed and will have to wait until their qualification is in demand. It can be concluded that changes in business requirements will lead to changes in the demand for labour (in this case graduates) in banking.

The issue of skills was also identified as a possible cause of graduate unemployment in the banking sector. The survey showed that employers require certain skills such as leadership skills, soft skills, management skills and cultural fit. A graduate without these skills might therefore not be employed. The results also suggest that employers do not regard university-based skills as sufficient. University-based skills might be too academic or not job related. They must therefore be supplemented with other skills.

Finally, it can also be deduced that although differences in expectations from employers and graduates could be a reason for graduate unemployment, higher salary expectations do not necessarily hinder graduates from gaining employment, as they usually aim for what the sector is offering. The economy is driven towards graduates who place value on their skills and what they have to offer; therefore, higher salary expectations might not necessarily be the cause of graduate unemployment.

The authors realise the danger of generalisation from a sample of 630 respondents and believe that this study should be repeated continuously to obtain a more comprehensive understanding of graduate unemployment in the banking sector over time. However, the study draws on actual primary data and therefore adds valuable perspectives on the perceptions of graduate unemployment in the banking sector.

The results of this study have several implications for universities, managers and policymakers. Most important is the realisation that graduate unemployment is detrimental to the economy in the long run. This study suggests a number of recommendations to reduce graduate unemployment.

In the first place, it is recommended that the skills shortage be addressed by organisations and educational institutions working together towards the implementation of appropriate programmes that would provide graduates with the necessary skills that are required in practice. Professional bodies have a role to play here. They usually interact with universities and play a role in the accreditation of programmes. The appropriate body in the banking industry can play an important role in this regard. Given that graduates are drawn from different degree groups, this envisaged engagement around skill requirement needs to be particularly structured.

Organisations and educational institutions can also work together to provide career guidance to graduates to ensure a selection of employable choices of subjects and courses. Working together can also assist in improving the quality of the so-called 'soft skills' that are also needed for graduates to successfully contribute to the productivity of organisations. These skills include team work skills, ethics in business interpersonal relationships, public speaking, meeting conduct and even time management skills. Government can help by providing graduate recruitment subsidies to improve the options of finding employment for young graduates.

The work done by SAGDA is potentially of significance here. SAGDA was hired by the Department of Trade and Industry (DTI) to implement and monitor their Unemployed Graduate Work Experience Placement programme. The programme aims to enhance graduates' employability by placing them in internship programmes. The programme assists graduates to gain relevant work experience through a 12-month internship programme in private sector companies. The DTI sources internship placements for unemployed graduates from companies that are receiving incentives from the DTI as well as those that are interested in the programme (DTI, 2014). The programme's vision is to provide relevant work experience to at least 1200 unemployed graduates over three intakes in the next 2 years from 2014 onwards. National Skills Fund within the Department of Higher Education and Training has approved funding to the value of R71 million over a 2-year period for monthly stipends of placed graduates, which will be managed by the DTI (DTI, 2014).

\section{Conclusion}

In final conclusion, the broader problem of graduate unemployment cannot be separated from the macro-economic picture of persistent long-run unemployment in South Africa. Unemployment in general also impacts graduates, although those leaving school early are even more adversely affected. Unless the National Development Plan's roadmap to reduce unemployment in South Africa is successfully implemented and yields sufficient results, unemployment in general and graduate unemployment, as a subset thereof, will exhibit the same persistency as is the case at the moment. The broader problem of graduate unemployment can only be solved 
in the long run if the overall problems in South Africa's schooling and educational system receive the attention they deserve. This will require the vision and will of dedicated leadership on a political and social level. Only then will the mass of unemployed graduates be replaced with a workforce that productively contributes to the South African society everyone desires.

\section{Acknowledgements}

The authors are grateful for the valuable comments and suggestions received from anonymous reviewers from the journal. All mistakes and omissions remain our own.

\section{Competing interests}

The authors declare that they have no financial or personal relationships that may have inappropriately influenced them in writing this article.

\section{Authors' contributions}

F.O. (University of Johannesburg) did most of the literature study and processing of the survey data and recording of the primary findings. D.B. (North-West University) formulated the original concept and assisted with the interpretation as well as the writing up of the results. L.G. (University of Johannesburg) assisted in the interpretation of the results and improvements on the first draft of the written work, whilst E.P.J.K. (North-West University) assisted with the final interpretation of the findings, the drafting of the final manuscript and technical processing and publication.

\section{References}

Altbeker, A., \& Storme, E. (2013). Graduate unemployment in South Africa. A much exaggerated problem, compiled by the centre for development and enterprise. Retrieved June 26, 2014, from http://www.cde.org.za/index.php/component/ content/article/83-jobs-and-growth/403-graduate-unemployment-in-southafrica-a-much-exaggerated-problem

Banerjee, A., Galiani, S., Levinsohn, J., McLaren, Z., \& Woolard, I. (2008). Why has unemployment risen in the New South Africa? The Economics of Transition, 16(4) 715-740. http://dx.doi.org/10.1111/j.1468-0351.2008.00340.x

BANKSETA. (2011). Sector skills plan update: 2010-2011. Retrieved August 08, 2012, from http://www.bankseta.org.za/downloads/BS_Annual_Report_FA_ Webversion.pdf

Barclays Africa Group Limited. (2013). BEE Report for the South African operations of Barclays Africa Group Limited. Retrieved September 27, 2014, from http://www.barclaysafrica.com/deployedfiles/Assets/Richmedia/PDF/Reports/ 2013/Barclays_Africa_Group_BEE_report_2013.pdf
Bhorat, H., \& Jacobs, E. (2010). An overview of the demand for skills for an inclusive growth path. Retrieved February 10, 2012, from http://www.dbsa.org/Research/ growth path. Retrieved $\% 20$
Higher $\% 20$ Education $\% 20$

Bhorat, H. \& Visser, M. (2010). Student graduation, labour market destinations and employment earnings. Pretoria, South Africa: Employment and Economic Policy Research Programme, Human Sciences Research Council.

Biavaschi, C., Eichhorst, W., Giulietti, C., Kendzia, M.J., Muravyev, A., Pieters, P. et al. (2013). Youth Unemployment and Vocational Training. Background paper for the World Development Report 2013. Washington, DC: World Bank.

Broekhuizen, H., \& Van der Berg, S. (2013). How high is graduate unemployment in South Africa? A much needed update. RESEP (Research on socio-economic policy), Department of Economics. University of Stellenbosch.

Daniel, R.C. (2007). Skills shortages in South Africa: A literature review. Development Policy Research Unit. Retrieved March 14, 2012, from http://www.commerce.uct. ac.za/research_units/dpru/?q=node/158

Department of Basic Education (DBE). (2011). South African country report: Progress on the implementation of the regional education and training plan. Pretoria, South Africa: DBE.

Department of Trade and Industry (DTI). (2014). Government to launch the internship programme for unemployed graduates. Retrieved September 29, 2014, from programme for unemployed graduates. Retrid
http:/www.dti.gov.za/editmedia.jsp?id=3007

Greener, S. (2008). Business research methods. Retrieved June 05, 2012, from http://kosalmath.files.wordpress.com/2010/08/introduction-to-researchmethods.pdf

Griesel, H., \& Parker, B. (2009). Graduate attributes: A baseline study on South African graduates from the perspective of employers. South Africa: HESA Press.

Levinsohn, J., Rankin, J., Roberts, G. \& Schöer, V. (2014). Wage subsidies and youth employment in South Africa: Evidence from a randomised control trial. Stellenbosch economic working papers 02/14. Retrieved November 05, 2014 from http://www.ilo.org/wcmsp5/groups/public/---ed_emp/documents/meeting document/wcms_237088.pdf

Lie, K. (2007). Employer perception on graduate literacy in higher education in relation to the workplace. Retrieved June 26, 2014, from http://www.esp-world.info/ Articles_20/DOC/Koo_vp_employer_Journal180ct09.pdf

Mlatsheni, C. (2005). The youth labour market: What does it take to succeed? Retrieved June 26, 2014, from http://www.ij.org.za/publications/pdfs/TA_2005_ complete.pdf

Moleke, P. (2010). The graduate labour market. Cape Town, South Africa: Employment and Economic Policy Research Programme, Human Sciences Research Council.

Naong, M. (2011). Promotion of entrepreneurship education: A remedy to graduates and youth unemployment. Journal of Social Science, 28(3), 181-189.

Oosthuizen, M. (2005). The post-apartheid labour market: 1995-2004. Cape Town South Africa: Development Policy Research Unit, University of Cape Town.

Pauw, K., Bhorat, H., \& Goga, S. (2006). Graduate unemployment in the context of skills shortages, education and training: Findings from a survey. Retrieved June 26,2014 , from http://papers.ssrn.com/sol3/papers.cfm?abstract_id=961353

South African Graduate Development Association (SAGDA). (2012). SAGDA database. Retrieved September 12, 2012, from http://www.sagda.org.co.za

Sha, N. (2006). Are graduates to be blamed? Unemployment of computer science graduates in Malaysia. Retrieved March 10, 2012, from http://aabss.org/ Perspectives2008/AABSS2008Article6NORSHIMAZSHAH.pdf

Sirat, M. \& Shuib, M. (2012). Employability of graduates in Malaysia. Bangkok, Thailand: Asian and Pacific Regional Bureau for Education, UNESCO.

Statistics South Africa. (2014). Quarterly labour force survey. Quarter 1, 2014 Statistical release P0211. Pretoria, South Africa: Statistics South Africa. Retrieved June 26, 2014, from http://beta2.statssa.gov.za/publications/P0211/ P02111stQuarter2014.pdf

Stemler, S. (2001). An overview of content analysis. Retrieved June 26, 2014, from http://pareonline.net/getvn.asp?v=7\&n=17

Weligamage, S. (2009). Graduates' employability: Evidence from literature review. Retrieved June 26, 2014, from http://www.kln.ac.lk/uokr/ASAIHL/SubThemeA8. pdf 